\title{
Quantitative evaluation of geological fluid evolution and accumulated mechanism: in case of tight sandstone gas field in central Sichuan Basin
}

\author{
Ya-Hao Huang ${ }^{1,2} \cdot$ You-Jun Tang ${ }^{1} \cdot$ Mei-Jun $\mathrm{Li}^{1,3} \cdot$ Hai-Tao Hong ${ }^{4} \cdot$ Chang-Jiang Wu ${ }^{4}$ Ji-Zhen Zhang ${ }^{1}$ Xiao-Lin Lu $^{3}$. \\ Xiao-Yong Yang ${ }^{1}$
}

Received: 11 February 2020 / Accepted: 3 December 2020 / Published online: 8 March 2021

(c) The Author(s) 2021

\begin{abstract}
Tight gas exploration plays an important part in China's unconventional energy strategy. The tight gas reservoirs in the Jurassic Shaximiao Formation in the Qiulin and Jinhua Gas Fields of central Sichuan Basin are characterized by shallow burial depths and large reserves. The evolution of the fluid phases is a key element in understanding the accumulation of hydrocarbons in tight gas reservoirs. This study investigates the fluid accumulation mechanisms and the indicators of reservoir properties preservation and degradation in a tight gas reservoir. Based on petrographic observations and micro-Raman spectroscopy, pure $\mathrm{CH}_{4}$ inclusions, pure $\mathrm{CO}_{2}$ inclusions, hybrid $\mathrm{CH}_{4}-\mathrm{CO}_{2}$ gas inclusions, and $\mathrm{N}_{2}$-rich gas inclusions were studied in quartz grains. The pressure-volume-temperature-composition properties $(P V T-x)$ of the $\mathrm{CH}_{4}$ and $\mathrm{CO}_{2}$ bearing inclusions were determined using quantitative Raman analysis and thermodynamic models, while the density of pure $\mathrm{CO}_{2}$ inclusions was calculated based on the separation of Fermi diad. Two stages of $\mathrm{CO}_{2}$ fluid accumulation were observed: primary $\mathrm{CO}_{2}$ inclusions, characterized by higher densities $\left(0.874-1.020 \mathrm{~g} / \mathrm{cm}^{3}\right)$ and higher homogenization temperatures $\left(>210{ }^{\circ} \mathrm{C}\right)$ and secondary $\mathrm{CO}_{2}$ inclusions, characterized by lower densities $\left(0.514-0.715 \mathrm{~g} / \mathrm{cm}^{3}\right)$ and lower homogenization temperatures: $\sim 180-200^{\circ} \mathrm{C}$ ). $\mathrm{CO}_{2}$ inclusions with abnormally high homogenization temperatures are thought to be the result of deep hydrothermal fluid activity. The pore fluid pressure (44.0-58.5 MPa) calculated from the Raman shift of C-H symmetric stretching $\left(v_{1}\right)$ band of methane inclusions is key to understanding the development of overpressure. PT entrapment conditions and simulation of burial history can be used to constrain the timing of paleo-fluid emplacement. Methane accumulated in the late Cretaceous ( 75-65 Ma), close to the maximum burial depth during the early stages of the Himalayan tectonic event while maximum overpressure occurred at $\sim 70 \mathrm{Ma}$, just before uplift. Later, hydrocarbon gas migrated through the faults and gradually displaced the early emplaced $\mathrm{CO}_{2}$ in the reservoirs accompanied by a continuous decrease in overpressure during and after the Himalayan event, which has led to a decrease in the reservoir sealing capabilities. The continuous release of overpressure to present-day conditions indicates that the tectonic movement after the Himalayan period has led to a decline in reservoir conditions and sealing properties.
\end{abstract}

Keywords Raman quantitative analysis $\cdot$ Fluid inclusions $\cdot$ Pore fluid pressure $\cdot$ Tight gas

Edited by Jie Hao and Chun-Yan Tang

You-Jun Tang

tyj@yangtzeu.edu.cn

1 Key Laboratory of Exploration Technologies for Oil and Gas Resources, Ministry of Education, College of Resources and Environment, Yangtze University, Wuhan 430100, China

2 Hubei Key Laboratory of Marine Geological Resources, China University of Geosciences, Wuhan 430074, China
3 State Key Laboratory of Petroleum Resources and Prospecting, College of Geosciences, China University of Petroleum (Beijing), Beijing 102249, China

4 Southwest Oil and Gas Field Branch Exploration and Development Research Institute, PetroChina Company Limited, Chengdu 610051, Sichuan, China 


\section{Introduction}

Tight sandstone gas (TSG) as an unconventional gas source has an extensive distribution and large resource potential worldwide (Jia et al. 2012; Dai et al. 2012a, b; Zou et al. 2012a, b; Arthur and Cole 2014). The term "tight sandstone gas" reservoirs usually refers to reservoirs with low permeability (less than $0.6 \mathrm{md}$ ), low porosity (less than 10\%) and a complicated pore structure (Guo et al. 2012; Lyu et al. 2017). It is estimated in 2012 that the current proven reserve of tight sandstone gas in the world is $3921 \times 10^{12} \mathrm{~m}^{3}$ (Zou et al. 2012a, b). To date sixteen, large tight sandstone gas fields (TSGFs) have been discovered in China in areas such as Ordos Basin, Sichuan Basin and Tarim Basin and the potential for the discovery of very large resources has led to increasing exploration emphasis on these plays (Dai et al. 2012a, b; Qiu et al. 2013). TSG reservoirs are frequently distributed continuously or semi-continuously on the slopes and in the centers of the basins and commonly have no distinct trap boundaries ( $\mathrm{Li}$ et al. 2013).

TSG exploration in Sichuan Basin has been dominated by Xujiahe Formation of Upper Triassic in West Sichuan Depression since the 1940s. At present, hydrocarbon resources are basically proven, and explorative extent remains stagnant (Xie et al. 2014; Wang et al. 2016). In 2019, with the discovery of new strata (Jurassic Shaximiao Formation) of high-yield industrial airflow in QL-16 and QL-17 wells, several Jurassic fluvial facies sand body in Jinhua, Qiulin and Yanting areas broke through successively (4.2-8.8 million $\mathrm{m}^{3} /$ day in single well; data come from Petro China Southwest Oil and Gasfield Company) and becomes the newest and largest producing TSG field in Sichuan basin, indicating the exploration and exploitation potential of Jurassic TSG in central Sichuan basin. Structure, fracture, and source rock are associated with the TSG distribution (Li et al. 2018; Zhao et al. 2019). However, the mechanism of tight gas enrichment in the central Sichuan Basin is not clear, multistage fluid activity is complex. The geochemical index of accurate restoration of paleo-fluid evolution can be used to study the mechanism of oil and gas accumulation (Haszeldine et al. 1984; Kareem et al. 2019). In particular, the indication of paleo-pressure evolution for the long-term effective preservation conditions as the key evidence (Guo et al. 2016) provides theoretical basis for further exploration and steady production of TSG in Sichuan Basin. The main control factors of natural gas accumulation can be systematically discussed by fluid quantification (Huang et al. 2020), in this regard, the pressure, temperature and compositional data on the geological fluids (diagenetic fluids and hydrocarbon fluids) can be determined by analysis of host minerals and fluid inclusions (Roedder and Bodnar 1980).
Laser Raman micro-spectroscopy (LRM) is a rapid, high precision, and nondestructive micro-analytical technique capable of in situ analysis (Zozulya et al. 1998). Because Raman spectroscopy is capable of quantitative analyses over a wide range of pressure-temperature conditions, it can directly determine the compositions and total densities of inclusions at both low and high temperatures (Seitz et al. 1996; Wang et al. 2019). Microthermometric measurement and laser Raman spectroscopy analyses performed on fluid inclusions can provide quantitative data on fluid inclusions (e.g., compositions, entrapped pressure, and bulk density), which when combined with thermodynamic modeling, can reconstruct P-T entrapment circumstance (Dubessy et al. 1989, 2001; Azbej et al. 2007). Laser confocal Raman micro-spectroscopy is used to measure $\mathrm{CH}_{4}$ and $\mathrm{CO}_{2}$ solubility, salinity, pressure, and density in individual gaseous and aqueous inclusions by means of peak shift, peak separation, peak area ratio, peak height ratio, and other parameters (Dubessy et al. 2001; Burke 2001; Baumgartner and Bakker 2009; Huang et al. 2020). Significantly, the paleo-pressures of methane inclusions can be accurately calculated with the approach of laser Raman spectroscopy, which provides direct evidence of the phase transformations and fluid evolution even in ultra-deep reservoirs.

The objectives of this study are to quantitatively characterize the changes in the reservoir fluid compositions, pressures, properties, and phases in the reservoirs and to define the fluid accumulation processes in tight sandstone reservoirs in the central Sichuan Basin. The principle research methods were mainly microthermometry, petrographic and optical observations (e.g., transmission light; cathodoluminescence), and laser Raman micro-spectrometry (LRM). These techniques were used to characterize the fluid inclusions according to their compositions, distributions, and host minerals. Micro-thermometry and quantitative Raman spectroscopy were used to determine the compositions, pressures, and thermal properties of the $\mathrm{CH}_{4}$ and $\mathrm{CO}_{2}$ gas fluid inclusions and these data were integrated with thermodynamic modeling to reconstruct the pore fluid pressure and overpressure history of the Shaximiao Formation. These results can then be applied to determine the timing of gas charging events, the reservoir pressure history, and analysis of the gas retention and gas loss in tight gas reservoirs in the Jurassic Shaximiao Formation.

\section{Geological setting}

The Sichuan Basin is a large oil and gas bearing intracratonic basin, which located in the Upper Yangtze stable craton, western China (Fig. 1a). The Jurassic Shaximiao Formation reserves reach to $2744.95 \times 10^{8} \mathrm{~m}^{3}$ and the daily gas production of individual intervals vary from 2 to 83 million 

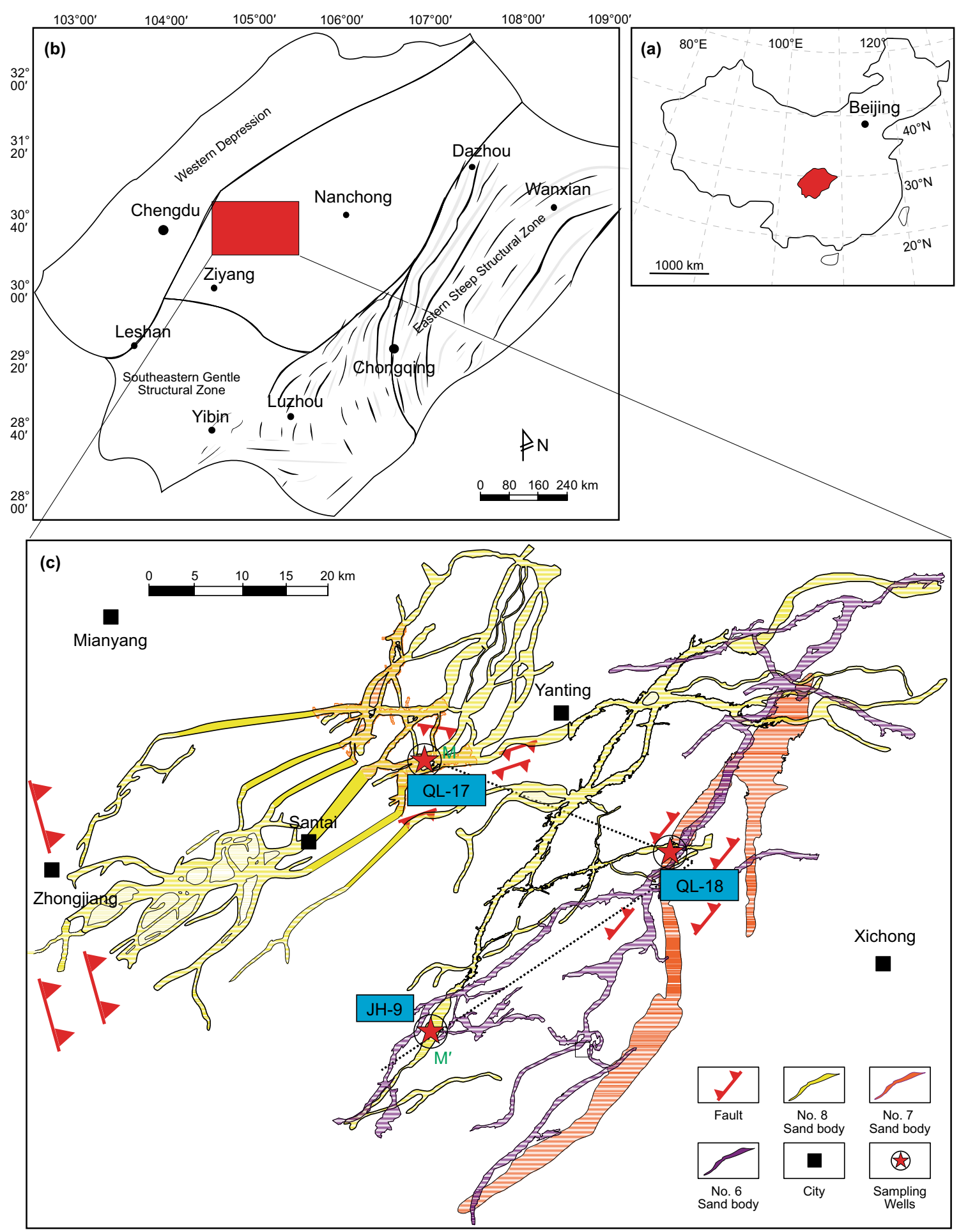

Fig. 1 a: Location of Sichuan Basin in China. b: Location of study area in central Sichuan Basin. c: Distribution of sand bodies of Jurassic gas fields, sampled wells, and the location of the geological cross section Fig. 2) in the central Sichuan Basin

cubic meters (data reported from Petro China Southwest Oil and Gasfield Company). The Qiulin and Jinhua tight gas fields located in the gentle structural belt of the Central Sichuan Basin (Fig. 1b). The Shaximiao Formation can be divided into the Upper Shaximiao Formation $\left(\mathrm{J}_{2} s^{2}\right)$ and Lower Shaximiao Formation $\left(\mathrm{J}_{2} s^{1}\right.$; Fig. 2). The Shaximiao Formation is composed primarily of purplish red and lightgray mudstone, gray-green fine sandstone and siltstone. 


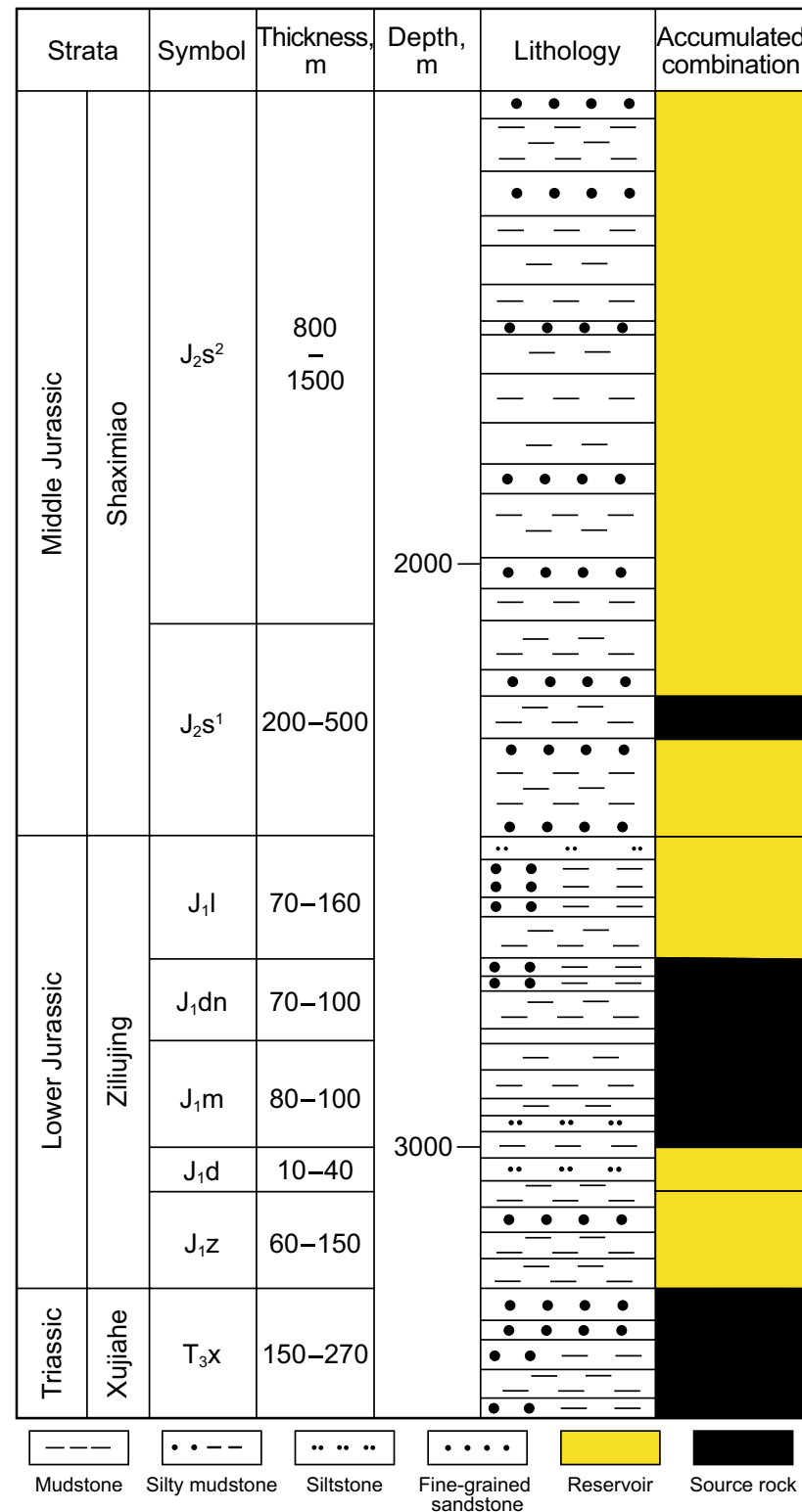

Fig. 2 Geological cross section of the wells in Jurassic Qiulin and Jinhua gas field

Three groups of channel sand bodies (named No. 6, 7, and 8: Petro China Southwest Oil and Gasfield Company) are the main producing intervals of tight sandstone gas in the Shaximiao Formation. The different sand bodies are strongly heterogeneous longitudinally (Fig. 1c) and are in direct contact with Jurassic and Triassic source rocks through a series of faults (Figs. 2 and 3).

The tectonics and structure of the Upper Triassic-Jurassic sediments in the Sichuan Basin were influenced by three tectonic episodes: the Indosinian Event (late Triassic), the Yanshan Event (Jurassic), and the Himalayan (early Cenozoic). The formation of tectonic depressions occurred mainly in the Indosinian period. During the Yanshanian period, the strata

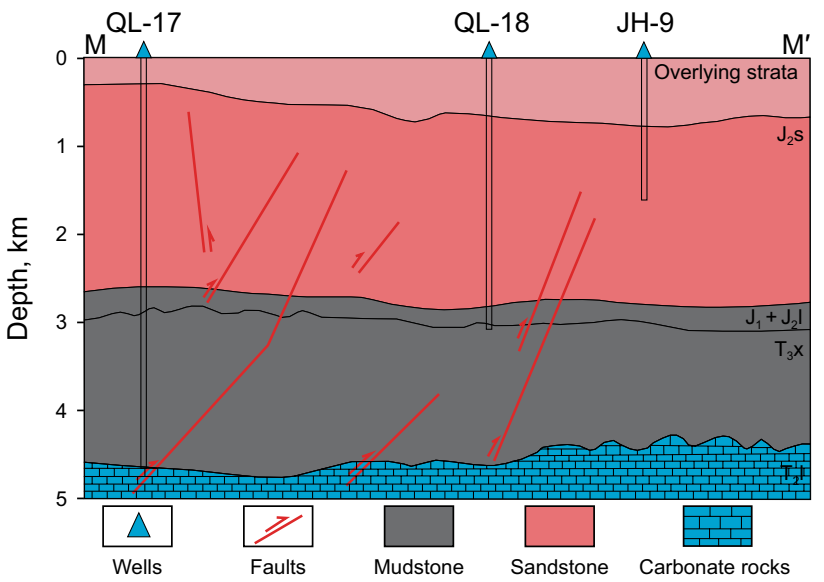

Fig. 3 Jurassic stratigraphic column of central Sichuan Basin (adopted from Li et al. 2011; Xiao et al. 2019)

underwent uplift and erosion, and the degree of denudation increased (Jiang et al. 2018). The Himalayan movement was the most intense tectonic event in basin and led to the occurrence of local tectonic deformation in the Upper Triassic and Jurassic strata. This local tectonism had significant influence on the migration, occurrences, and fluid properties of the natural gas in the basin (Guo et al. 2012; Wang et al. 2015).

Exploration results demonstrate that the reservoir conditions in the channel sands are favorable for shallow oil and gas accumulations (Guo et al. 2018). The porosity of the reservoirs in the Shaximiao reservoirs ranges from 0.4 to 9.6 $\%$, with an average of $4.5 \%$, and the average permeability is approximately $0.23 \mathrm{mD}$, both of which are characteristic of classical ultra-low porosity and ultra-low permeability tight reservoirs. The primary types of storage space include residual primary intergranular pores, intergranular pores, and micro-fractures (Liu et al. 2010). Gas/source correlations show that the reservoir gases were primarily generated in the lower Triassic Xujiahe source rocks (Xiao et al. 2019). The reservoired gas is rich in methane (84.89-97.34\%), and $\mathrm{C}_{2+}$ concentrations range from $2.42-13.53 \%$. The non-hydrocarbon gases are primarily $\mathrm{N}_{2}$ and $\mathrm{CO}_{2}$, with a total content ranging from 0.00-1.49\% (Xiao et al. 2019).

\section{Samples and analytical methods}

Approximately 15 TSG core samples were collected from the QL-17, QL-18, and JH-9 borehole of Shaximiao Formation $\left(\mathrm{J}_{2} s\right)$ in Central Sichuan Basin (Fig. 1). Standard logging interpretation was used to select specific gas producing intervals for sampling. The reservoirs samples are mainly multiperiod channel sand bodies. Sample depths from the QL-17 well range from 2166.8 to $2168.2 \mathrm{~m}$, sample depths from the QL-18 well vary from 2087.1 to $2093.1 \mathrm{~m}$ and 
sample depths from the JH-9 range from 2911.82 to 2912.38 m (Table 1).

Doubly polished thin sections $(\sim 200 \mu \mathrm{m})$ were prepared for fluid inclusion studies using Canada balsam. Residual organic matter and migrated hydrocarbons in the samples can produce fluorescence effects which can obscure the weaker Raman signals from the compositional material (Frezzotti et al. 2012). To mitigate organics interference, core sheets were immersed in methylene chloride and methanol for 3-5 hours until the sheets are detached from the glass.

A petrographic examination was carried out under transmitted visible light with up to $10 \mathrm{X}, 20 \mathrm{X}, 50 \mathrm{X}$, and $100 \mathrm{X}$ magnification using an Olympus BX51 microscope. Thermodynamics measurements of the fluid inclusions were carried out using TH-600 heating-cooling stage (Linkam). The homogenization temperatures $\left(T_{\mathrm{h}}\right)$ of fluid inclusions were measured by thermodynamic cycle and standard deviation of instrument keep in $1^{\circ} \mathrm{C}$ (Shepherd et al. 1985). Temperature controlled in $0.5^{\circ} \mathrm{C} / \mathrm{min}$ for unit until the phase differentiation disappeared or freezing point appeared. The heat-cooling stage stood stable for $2 \mathrm{~min}$ and obtained the $T_{\mathrm{h}}$, repetitive increase or decrease temperature for verification. The phase transitions during thermal measurement and molar volumes of binary $\mathrm{CO}_{2}-\mathrm{CH}_{4}$ system are described by Thiery et al. (1994) and van den Kerkhof (2001).

Cathode luminescence (CL) analysis can be used to distinguish quartz from calcite and to identify different generations of cement (Mason 2006). A selection of polished thin sections was analyzed using a CL8200 MK5 cathode luminescence system coupled to a Leica DM2500 camera. The beam conditions were: beam voltage: $17 \mathrm{kV}$, beam current:
$500 \mu \mathrm{A}$. All CL images were obtained with the same exposure time $(70 \mathrm{~ms})$ and gain $(1.005 \mathrm{~s})$.

Laser Raman micro-spectroscopy (LRM) was used to analyze the compositions of the gases trapped within fluid inclusions in fracture-healed quartz or cements. The Raman system was a JY/Horiba LabRam HR800 (frequency multiplication neodymium-doped yttrium aluminum garnet laser, $532.06 \mathrm{~nm}$, output laser power of $400-500 \mathrm{~mW}$ ) at Wuhan University of Geosciences, China and objective with a 0.5 numerical aperture. Gaseous fluid inclusions were investigated using a $200 \mu \mathrm{m}$ confocal aperture, and Raman peak calibration was accomplished with the $520.7 \mathrm{~cm}^{-1}$ band of a polished silicon wafer. The compositions of the gases in the fluid inclusions were analyzed using the $300 \mathrm{gr} \cdot \mathrm{mm}^{-1}$ grating and $2650 \mathrm{~cm}^{-1}$ grating center. Spectrum was collected in the $1200-4000 \mathrm{~cm}^{-1}$ range. The collection time ranged from 0 to 50 seconds and $200-500$ scans were acquired per sample in order to acquire the signal-to-noise ratio. For single-phase inclusions, high-resolution techniques (an $1800 \mathrm{gr} \cdot \mathrm{mm}^{-1}$ grating and narrow slit of $50 \mu \mathrm{m}$ ) were used to enhance the resolution of the peak positions. A Ne lamp was laid under the objective to collect the $\mathrm{Ne}$ emission line spectra for wavelength calibration purposes (Kawakami et al. 2003; Dubessy et al. 2012; Zhang et al. 2016).

The regular shift of methane stretching vibration peak $\left(v_{1}\right)$ with density fluctuation can be used to determine the density of pure methane gas inclusions (Seitz et al. 1993, 1996; Lin 2005; Lu et al. 2007) at $25^{\circ} \mathrm{C}$ using homogenized samples. After the acquisition of the Raman spectra, $P V T-x$ of pure methane gas inclusions can be determined by following the methodology described by Zhang et al. (2016). The densities of single-phase $\mathrm{CO}_{2}$ inclusions were determined from

Table 1 Pure $\mathrm{CH}_{4}$ inclusions Raman quantitative analysis summary

\begin{tabular}{|c|c|c|c|c|c|c|c|}
\hline No. & Well & Depth, m & $v_{\text {true }}, \mathrm{cm}^{-1}$ & Density, $\mathrm{g} / \mathrm{cm}^{3} * \mathrm{a}$ & $\begin{array}{l}\text { Coeval aqueous inclusions } \\
\text { homogenization temperature, }{ }^{\circ} \mathrm{C}\end{array}$ & $\begin{array}{l}\text { Trapped pres- } \\
\text { sure, } \mathrm{MPa} * \mathrm{~b}\end{array}$ & $\begin{array}{l}\text { Pressure } \\
\text { coefficient }\end{array}$ \\
\hline 1 & QL-17 & 2166.8 & 2911.95 & 0.230 & 130.0 & 56.9 & 1.32 \\
\hline 2 & QL-17 & 2166.8 & 2912.30 & 0.210 & 128.0 & 49.1 & 1.14 \\
\hline 3 & QL-17 & 2168.2 & 2911.91 & 0.229 & 121.5 & 54.5 & 1.43 \\
\hline 4 & QL-17 & 2168.2 & 2911.98 & 0.225 & 122.5 & 53.3 & 1.38 \\
\hline 5 & QL-17 & 2182.2 & 2911.85 & 0.232 & 127.0 & 57.0 & 1.36 \\
\hline 6 & QL-17 & 2182.2 & 2912.60 & 0.195 & 127.0 & 44.0 & 1.05 \\
\hline 7 & QL-18 & 2093.1 & 2911.75 & 0.237 & 125.0 & 58.5 & 1.43 \\
\hline 8 & QL-18 & 2093.1 & 2912.06 & 0.220 & 125.0 & 52.0 & 1.27 \\
\hline 9 & QL-18 & 2087.1 & 2912.03 & 0.220 & 127.0 & 52.4 & 1.25 \\
\hline 10 & QL-18 & 2087.1 & 2912.10 & 0.219 & 124.0 & 51.4 & 1.25 \\
\hline 11 & JH-9 & 2212.9 & 2912.38 & 0.210 & 120.0 & 47.5 & 1.25 \\
\hline 12 & JH-9 & 2212.9 & 2911.82 & 0.230 & 126.4 & 56.1 & 1.34 \\
\hline 13 & JH-9 & 2212.9 & 2911.86 & 0.230 & 126.4 & 56.1 & 1.34 \\
\hline
\end{tabular}

*a: Density calculated following Zhang et al. (2016)

*b: Trapped pressure calculated following Peng and Robinson (1976) 
the differences in wavenumber between the two peaks of the Fermi diad of $\mathrm{CO}_{2}$, with the application of the neon peak shift correction (Rosso and Bodnar 1995). The spectra of the $\mathrm{CO}_{2}$ inclusions were collected at $160^{\circ} \mathrm{C}$ to ensure complete homogenization and the densities of $\mathrm{CO}_{2}$ calculated using the multiple regression methods described by Huang et al. (2018).

The burial and thermal histories were modeled using the BasinMod-1D (Version 7.06) software, which integrates the stratigraphic thickness, lithology, absolute age, erosional thickness, and measured borehole temperature data in order to calculate the heat flow and vitrinite reflectance histories through time. Measured vitrinite reflectance values and borehole temperature data were obtained from well completion reports supplied by the Petro China Southwest Oil and Gasfield Company. The modeling process was primarily calibrated using measured vitrinite reflectance values and corrected borehole temperatures.

\section{Results}

\subsection{Fluid inclusion characteristics}

\subsubsection{Petrology of fluid inclusions}

Both $\mathrm{CH}_{4}$ and $\mathrm{CO}_{2}$ bearing fluid inclusions can be trapped together in micro-fractures and overgrowths on quartz crystals (Fig. 4). Primary fluid inclusions are those that are trapped during the initial diagenesis and crystallization of
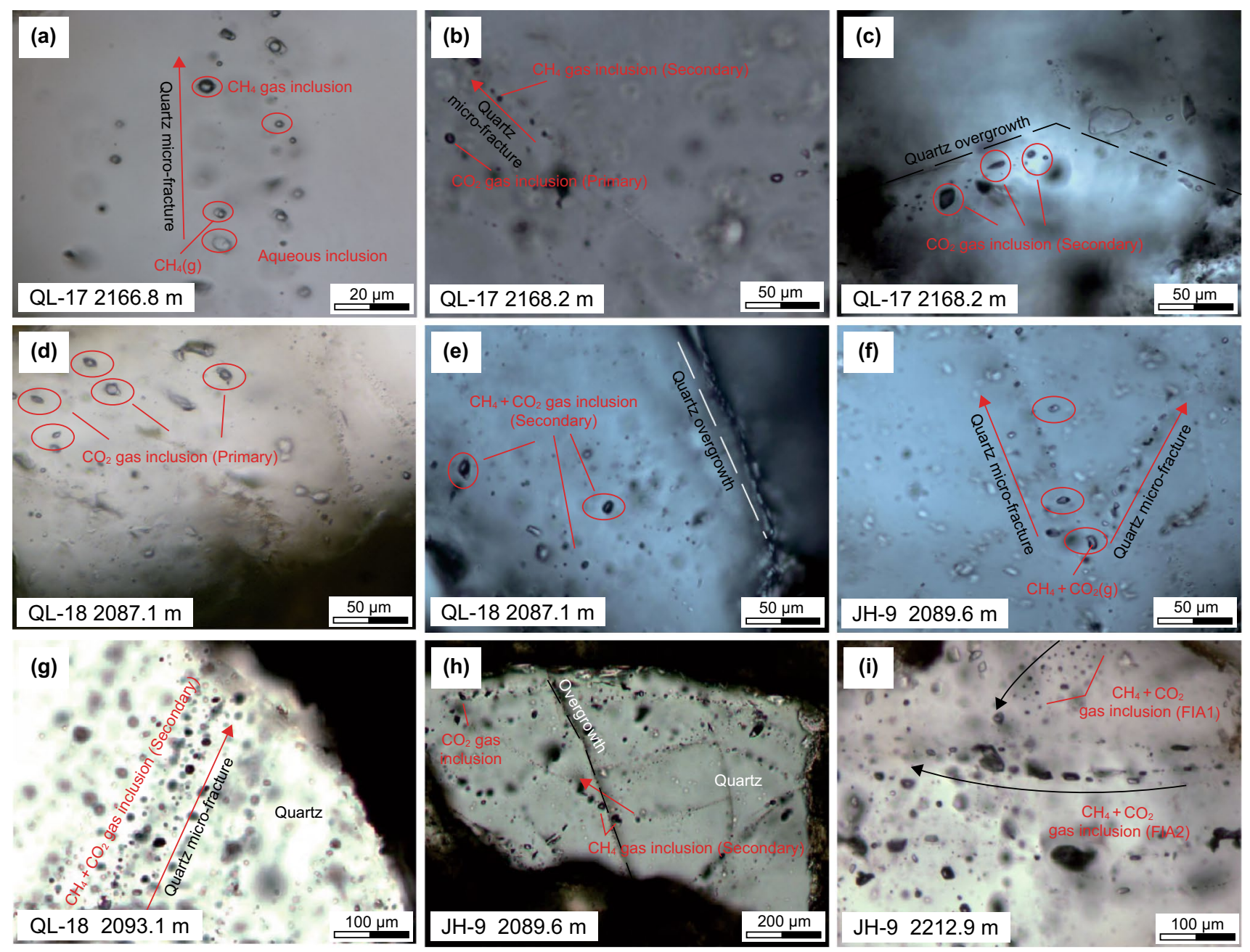

Fig. 4 a Pure $\mathrm{CH}_{4}$ gas inclusions exist as linear distribution in healed micro-fracture coeval with aqueous inclusion; $\mathbf{b} \mathrm{CH}_{4}$ gaseous inclusions exist in quartz overgrowth and $\mathrm{CO}_{2}$ gaseous inclusions exist isolated in grain; $\mathbf{c}$ Pure $\mathrm{CO}_{2}$ gas inclusions exist in overgrowths of quartz; $\mathbf{d}$ Abundant pure $\mathrm{CO}_{2}$ inclusions distribute as clusters in quartz grain; $\mathbf{e}$ Hybrid $\mathrm{CH}_{4}-\mathrm{CO}_{2}$ gaseous inclusions exist in quartz overgrowths; $\mathbf{f}$ and $\mathbf{g}$ Hybrid $\mathrm{CH}_{4}-\mathrm{CO}_{2}$ gaseous inclusions exist in healed micro-fractures; $\mathbf{h}$ Macro perspective shows that secondary $\mathrm{CH}_{4}$ gas inclusions cross over the quartz grain and overgrowths. $\mathrm{CO}_{2}$ gas inclusions only exist in overgrowths; $\mathbf{i}$ : Two types of hybrid inclusions with different molar ratios of $\mathrm{CH}_{4}$ and $\mathrm{CO}_{2}$ are existed in two intersecting fractures. All components were identified by micro-Raman spectroscopy 
the rock, while secondary origin inclusions trapped during overgrowth and precipitation of fracture- and vein-filling cements. Cathode luminescence photomicrographs show that the color of quartz overgrowths is different from that of quartz grains, which assists in identifying fluid inclusions, and the entrapment zone of secondary fluids can be further defined by combining cathode luminescence photomicrographs with those from single polarized light (Fig. 5).

Fluid inclusions assemblages (FIA) can be classified into four types based upon petrographic observations at room temperature and Raman analysis.

Inclusion type I: This FIA type is single-phase $\left(\mathrm{VCH}_{4}\right)$ gas inclusions found along healed microfractures and coeval with aqueous inclusions (Fig. 4a, b) implying secondary origin. Diameters of gas inclusions range from 5 to $11 \mu \mathrm{m}$.

Inclusion type II: These vapor-rich inclusions are twophase inclusions $\left(\mathrm{LCO}_{2}+\mathrm{VCO}_{2}\right)$ and coeval with aqueous inclusions. They primarily occur as clusters in quartz grains or linear arrays in quartz overgrowths (Fig. 4b, c, d). The diameters vary from $8-15 \mu \mathrm{m}$. These inclusions represent both primary and secondary origins, but with different timing of formation. They generally have elliptical to circular shapes. In Fig. 4h, secondary pure $\mathrm{CH}_{4}$ gas inclusions cut across the quartz grain and overgrowths and isolated inclusions of pure $\mathrm{CO}_{2}$ occur in overgrowths, which indicates $\mathrm{CH}_{4}$ fluid was trapped later than $\mathrm{CO}_{2}$ fluid.
Inclusion type III: These inclusions contain $\mathrm{CH}_{4}$ vapor (V) or $\mathrm{CO}_{2}$ vapor. These inclusions are commonly coeval with aqueous inclusions (Fig. 4e, f, g) with sizes ranging from $7-13 \mu \mathrm{m}$ and generally occur along microfractures and in quartz overgrowths. In Fig. 4i, a mixed gas inclusion exists in the position of the intersection of two conjugated healed fractures (horizontal micro-fracture and the vertical micro-fracture). On account of long axis direction of fluid inclusions in accordance to the fracture distribution of FIA2, which indicates that FIA2 was grew later than FIA1 from petrographic examination (Goldstein 2003).

Inclusion type IV: Rich nitrogen and bearing small amounts of $\mathrm{CO}_{2}$ inclusions (Fig. 8d) distributes along microfractures. The diameters range in size from 5 to $9 \mu \mathrm{m}$.

\subsubsection{Microthermometry}

Microthermometric measurements were performed on aqueous inclusions coexisting with the four types of gas inclusions described above. The salinities (wt.\% $\mathrm{NaCl}$ equivalent) of these fluid inclusions were calculated based on their final ice-melting temperatures ( $T_{\mathrm{m} \text {, ice; }}$ Hall et al. 1988). The Raman and microthermometric data and the calculated density and pressure parameters for these fluid inclusions are summarized in Tables 1, 2 and illustrated in Fig. 6. The homogenization temperatures of aqueous inclusions coeval with type I inclusions range from 115.0 to $160.0{ }^{\circ} \mathrm{C}$,
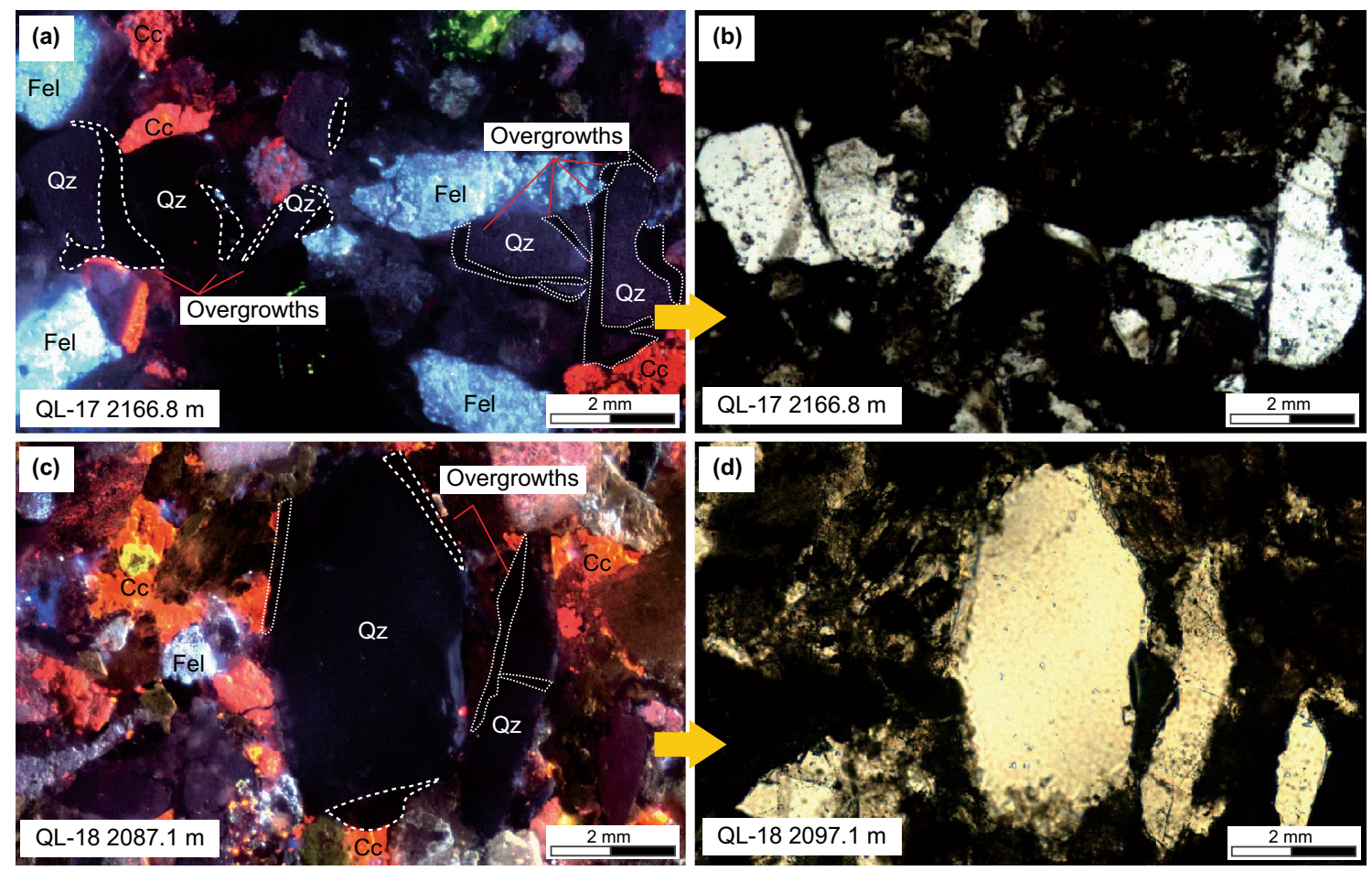

Fig. 5 Cathodoluminescence and plane-polarized light photomicrographs of reservoir sandstones in Shaximiao Formation; Qz: Quartz, Cc: Carbonate cements, Fel: Feldspar 
Table 2 Pure $\mathrm{CO}_{2}$ inclusions Raman quantitative analysis summary

\begin{tabular}{|c|c|c|c|c|c|c|}
\hline No. & Well & Depth, m & $\begin{array}{l}\text { Distance of fermi } \\
\text { doublet, } \mathrm{cm}^{-1}\end{array}$ & Density, $\mathrm{g} / \mathrm{cm}^{3} *_{\mathrm{a}}$ & $\begin{array}{l}\text { Coeval saline inclusion homogeni- } \\
\text { zation temperature, }{ }^{\circ} \mathrm{C}\end{array}$ & $\begin{array}{l}\text { Trapped pres- } \\
\text { sure, } \mathrm{MPa} * \mathrm{~b}\end{array}$ \\
\hline 1 & QL-17 & 2168.2 & 103.48 & 0.514 & 193.0 & 41.3 \\
\hline 2 & QL-17 & 2168.2 & 104.35 & 0.921 & 188.5 & 114.8 \\
\hline 3 & QL-17 & 2182.2 & 103.91 & 0.701 & 201.3 & 68.4 \\
\hline 4 & QL-17 & 2182.2 & 104.35 & 0.921 & 203.5 & 122.9 \\
\hline 5 & QL-18 & 2093.1 & 103.85 & 0.673 & 189.1 & 60.1 \\
\hline 6 & QL-18 & 2093.1 & 103.94 & 0.715 & 189.1 & 66.8 \\
\hline 7 & QL-18 & 2087.1 & 104.26 & 0.874 & 223.3 & 117.5 \\
\hline 8 & QL-18 & 2087.1 & 104.44 & 0.970 & 245 & 165.9 \\
\hline 9 & QL-18 & 2087.1 & 104.53 & 1.020 & 245 & 191.1 \\
\hline
\end{tabular}

*a: Density calculated following Wang et al. (2019)

*b: Trapped pressure calculated following Peng and Robinson (1976)

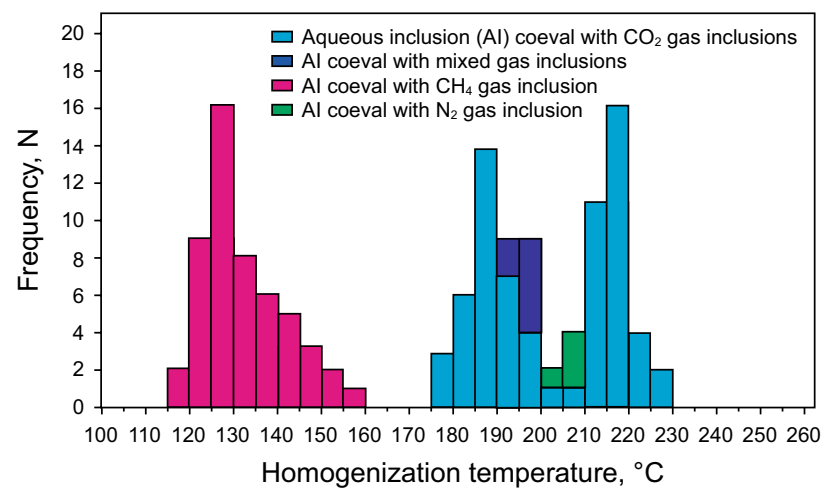

Fig. 6 Homogenization temperature statistics of aqueous inclusions in Shaximiao Formation

with a well-defined maximum distribution between 120 and $130{ }^{\circ} \mathrm{C}$. The homogenization temperatures of aqueous inclusions coeval with type II inclusions range from 175.0 to $230.0{ }^{\circ} \mathrm{C}$, with a well-defined maximum distribution between 185 and $190^{\circ} \mathrm{C}$ and $210.0-220.0^{\circ} \mathrm{C}$. $T_{\mathrm{h}}$ of aqueous inclusions coeval with type IV inclusions range from 200.0 to $210.0{ }^{\circ} \mathrm{C}$ (Fig. 6). $T_{\mathrm{m}}$ of aqueous inclusions coeval with pure $\mathrm{CH}_{4}$ inclusions vary between -10.1 and $-13.8{ }^{\circ} \mathrm{C}$, with salinities ranging from 14.0 to $17.6 \mathrm{wt} . \% \mathrm{NaCl}$ equiv. The ice-melting temperature of aqueous inclusions coeval with pure $\mathrm{CO}_{2}$ inclusions varies between -4.9 and $-1.7{ }^{\circ} \mathrm{C}$, with calculated salinities ranging from 0.92 to $2.30 \mathrm{wt} . \%$ $\mathrm{NaCl}$ equiv.

Inclusions with mixed $\mathrm{CH}_{4}-\mathrm{CO}_{2}$ gaseous components were also found to occur. These samples were initially distinguished by their $\mathrm{C}-\mathrm{H}$ symmetric stretching band $\left(\sim 2917 \mathrm{~cm}^{-1}\right)$ and Fermi diads $\left(\sim 1280 \mathrm{~cm}^{-1}\right.$ and $\sim 1380$ $\left.\mathrm{cm}^{-1}\right)$ at $100.0^{\circ} \mathrm{C}$ (keep inclusions at homogeneous state). Subsequently, decreased temperature to $-120.0^{\circ} \mathrm{C}$, complete freezing inclusions into solid (S) phase. During this thermal measurement, the carbonic inclusions homogenized to a liquid (L) phase, on the contrary, $\mathrm{CH}_{4}$-rich inclusion homogenized to a gas phase. In the terminal-origin hybrid gas inclusions (e.g., FIA2), the melting of $\mathrm{CO}_{2}\left(T_{\mathrm{m}, \mathrm{carb}}\right)$ $(\mathrm{L}+\mathrm{V} \rightarrow \mathrm{SV} \rightarrow \mathrm{LV})$ occurred between -67.9 and $-69.4{ }^{\circ} \mathrm{C}$. Since $T_{\mathrm{m} \text {, carb }}$ is lower than that of single-phase $\mathrm{CO}_{2}(-62.3$ to $\left.-63{ }^{\circ} \mathrm{C}\right)$, the reduction of the freezing point indicates that $\mathrm{CH}_{4}$ must also be present in the inclusion and take responsibility of the observed $T_{\mathrm{m}}$ reduction. Homogenization temperatures $\left(T_{\mathrm{h}, \text { carb }}\right)$ of hybrid gas inclusions (yellow dots in Fig. 7) vary from -12.3 to $-19.8{ }^{\circ} \mathrm{C}$ and -63.1 to $-69.2{ }^{\circ} \mathrm{C}$. The concentration of $\mathrm{CH}_{4}$ can be determined from the $T_{\mathrm{m} \text {, carb }}$ and $T_{\mathrm{h} \text {, carb }}$ as described by Thiery et al. (1994). Thermodynamics measured results show molar proportion of $\mathrm{CH}_{4}$ not exceeding $30 \%$ and the molar proportion of $\mathrm{CO}_{2}$ vary from $75 \%$ to $77 \%$. Contrast with their petrographic characteristics, significantly higher concentrations of $\mathrm{CH}_{4}(75 \%-77 \%)$ inclusions were entrapped later than the low concentrations of $\mathrm{CH}_{4}(23 \%-26 \%)$ inclusions (Fig. 7).

\subsubsection{Gaseous inclusion quantitative analysis by Raman spectroscopy}

Pressure and density of methane fluid inclusions in quartz minerals can be measured using quantitative Raman analysis (Huang et al. 2020; Zhang et al. 2016). Figure 8a-a shows a typical Raman spectrum of single-phase methane inclusions acquired at homogeneous state. Table 1 lists the data for 13 type I inclusions, including the data of densities, determined from the $v_{1}$ symmetric stretching band of $\mathrm{CH}_{4}$. Overall, the density of secondary pure $\mathrm{CH}_{4}$ fluid inclusions in quartz minerals range from 0.195 to $0.237 \mathrm{~g} / \mathrm{cm}^{3}$ (average value: $0.222 \mathrm{~g} / \mathrm{cm}^{3}$ ).

Table 2 shows the data for nine pure $\mathrm{CO}_{2}$ inclusions, which were analyzed by the Fermi diads (double peaks) of $\mathrm{CO}_{2}$ at homogenization condition (Fig. 8b). The pure $\mathrm{CO}_{2}$ 


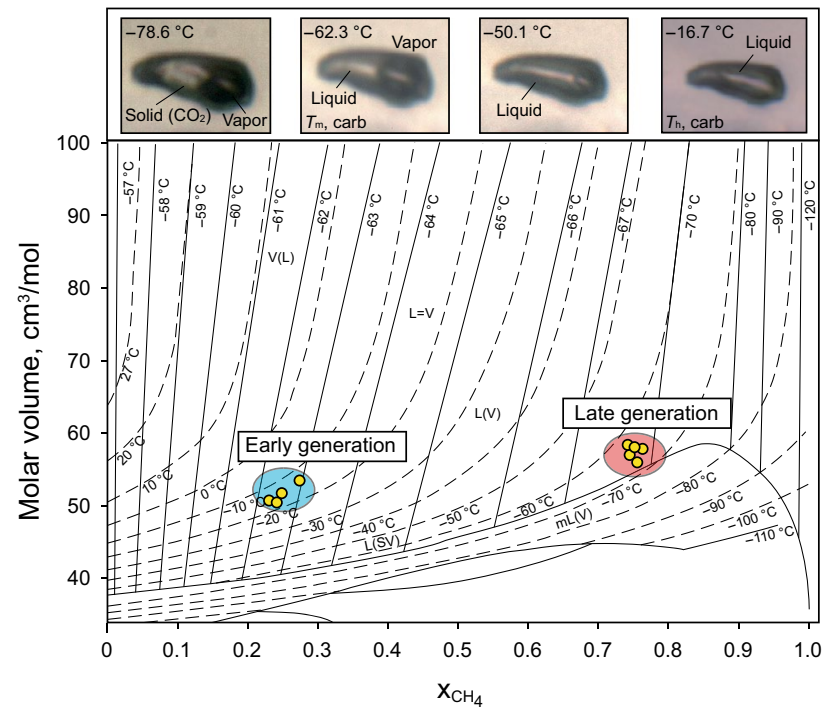

Fig. 7 Photomicrographs of phase transition processes during determination of melting temperature $\left(T_{\mathrm{m}, \text { carb }}\right)$ and homogenization temperatures $\left(T_{\mathrm{h}, \text { carb }}\right)$ for hybrid gas inclusions in the Shaximiao Formation. Inclusions of different petrographic generations shown different gas concentrations. Black lines define the melting temperature of the solid phase, dashed lines represent isothermal conditions of homogenization; $\mathrm{V}(\mathrm{L})=$ stability field of the vapor phase; $\mathrm{L}=\mathrm{V}=$ liquid and vapor phase are in equilibrium; $\mathrm{L}(\mathrm{V})=$ stability field of the liquid phase; $\mathrm{L}(\mathrm{SV})=$ tie-line joining the field of liquid phase in coexistence with a vapor and a solid phase; for a detailed explanation refer to Thiery et al. 1994, the original chart is adopted from Huang et al. 2020
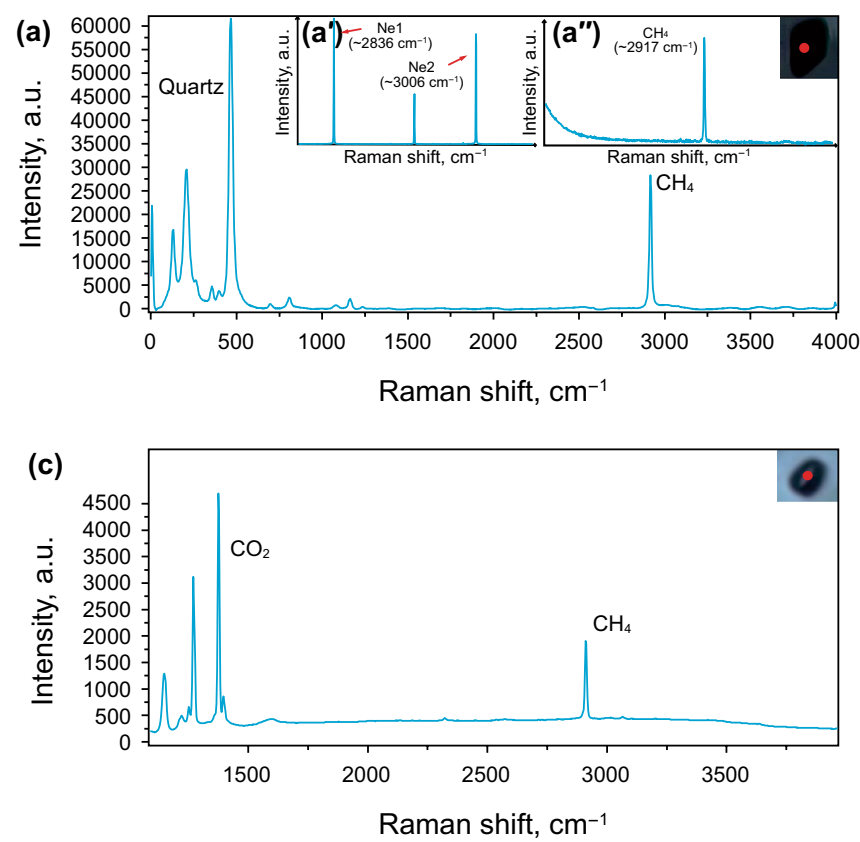

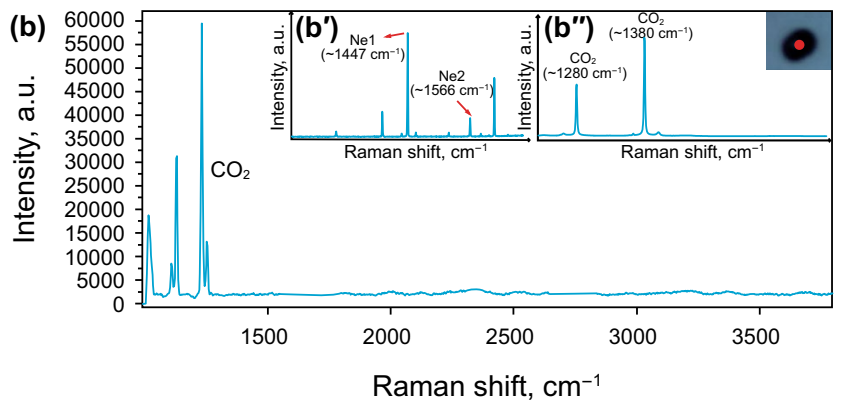

inclusions can be divided into two classes primary $\mathrm{CO}_{2}$ inclusions with densities ranging from 0.874 to $1.020 \mathrm{~g} / \mathrm{cm}^{3}$ (average value: $0.941 \mathrm{~g} / \mathrm{cm}^{3}$ ) and secondary inclusions with densities varying between 0.514 and $0.715 \mathrm{~g} / \mathrm{cm}^{3}$ (average value: $0.651 \mathrm{~g} / \mathrm{cm}^{3}$ ). The homogenization pressures were calculated using the Peng-Robinson equation of state (EOS) model (1960), which uses the densities and homogenization temperatures of the coexisting aqueous inclusions.

The occurrence of fluid inclusions with highly variable gas-liquid ratios in a single fluid inclusion assemblage (FIA) indicates that the pure $\mathrm{CH}_{4}$ and $\mathrm{CO}_{2}$ inclusions and the aqueous saline inclusions were trapped under immiscible entrapment conditions. Consequently, homogenization P-T is correspond to the entrapment conditions (Diamond 2001; Goldstein 2003). As a result, the thermodynamic systems integrate with the Raman spectroscopy calibration can determine the compositions and densities of the multiphase and multicomponent fluids (Peng and Robinson 1960; Duan and Mao 2006; Becker et al. 2008; Lecumberri-Sanchez et al. 2012; Mao et al. 2013).

Pressure coefficient $\left(P_{\mathrm{c}}\right)$ here refers to the actual formation fluid pressure $\left(P_{\mathrm{f}}\right)$ divided by normal hydrostatic pressure $\left(P_{\text {hyd }}\right)$ in the same position, and it is one of the primary indicators of abnormal reservoir pressure (Law and Spencer 1998). Trapped pressures of pure $\mathrm{CH}_{4}$ inclusions vary between approximately 44.0 and $58.5 \mathrm{MPa}$ (Table 1). Estimated paleo-depth against the trapped pressure of fluid

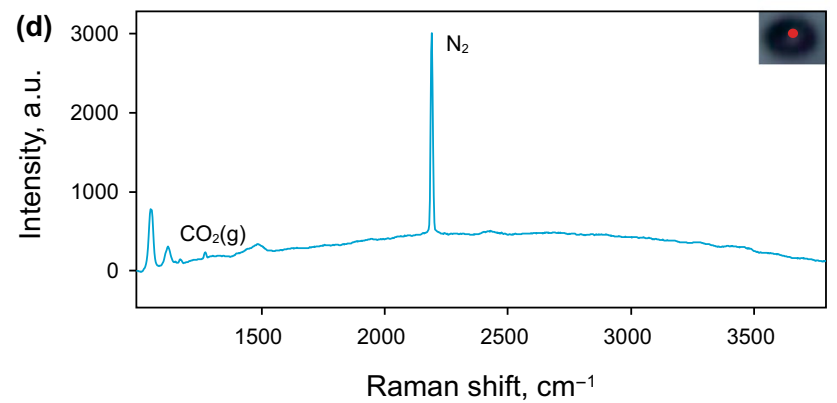

Fig. 8 a: Spectrum of pure $\mathrm{CH}_{4}$ collected using 300 gr.mm ${ }^{-1}$ grating in quartz; (a'): wave number calibration using the Ne emission spectrum; (a'): $\mathrm{CH}_{4}$ symmetric stretching band $\left(v_{1}\right)$ peak was collected using 1800 gr.mm ${ }^{-1}$ grating with $\mathrm{Ne}$ lamp; b: Spectrum of pure $\mathrm{CO}_{2}$ acquired using a 300 gr.mm ${ }^{-1}$ grating in a homogeneous state; (b') Ne emission spectrum for wave number calibration; (b"): $\mathrm{CO}_{2}$ Fermi double peaks were collected using 1800 gr.mm ${ }^{-1}$ grating with Ne lamp; c: Spectrum of a hybrid gas inclusion collected using a 300 gr. $\mathrm{mm}^{-1} \mathrm{grating}$; d: Spectrum of a $\mathrm{N}_{2}$-rich inclusion collected using 300 gr.mm ${ }^{-1}$ grating in quartz 
inclusions plotted the paleo $P_{\mathrm{c}}$ (Fig. 9, hydrostatic gradient of $10.00 \mathrm{MPa} / \mathrm{km}$ and the lithostatic gradient of $24.99 \mathrm{MPa} /$ $\mathrm{km}$ for comparison). Take into accounts of density log data for the well QL-17 calculated with a depth-averaged rock density and a water column with an average seawater density, the lithostatic gradient was $2.55 \mathrm{~g} / \mathrm{cm}^{3}$, and the hydrostatic gradient was $1.01 \mathrm{~g} / \mathrm{cm}^{3}$. As can be seen in Fig. 9, most of the samples are weakly overpressured.

\subsection{Basin model}

The burial and thermal histories were simulated to determine the present-day porosity-depth relationship in order to correct the present-day burial depths for decompaction effects (Falvey 1981). The initial porosities and lithologies (shale/mudstone, sandstone, siltstone, and limestone) were

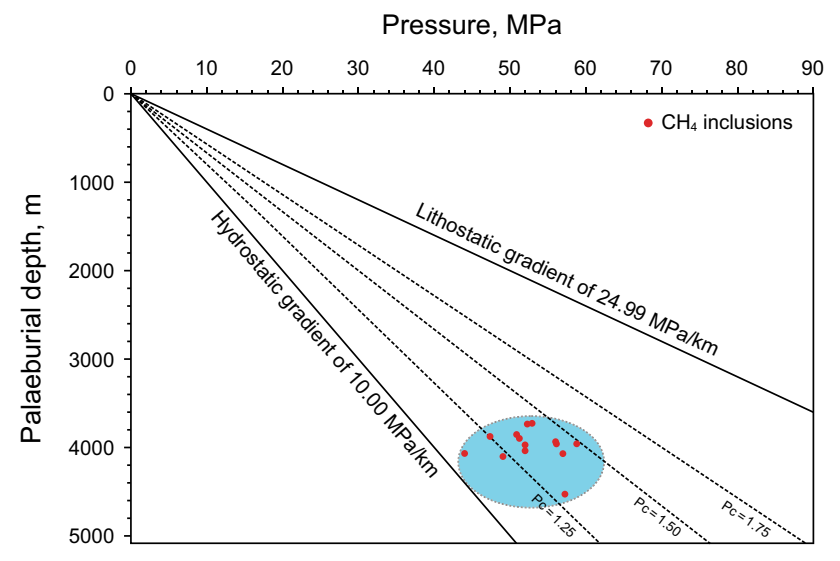

Fig. 9 Calculated entrapment pressures plotted against inferred paleoburial depth $\left(P_{\mathrm{c}}\right.$ : Pressure coefficient) adopted as the default values in the BasinMod software. The depth and absolute age data for each stratigraphic unit were obtained from Petro China Southwest Oil and Gasfield Company. The eroded thickness, tectonic subsidence, hydrocarbon generation, paleo-burial depth and paleo-heat flow data were obtained from Guo et al. (2018) and Lin et al. (2017). The thermal conductivities of the rock units can be used to calculate the present-day heat flow based on the transient heat flow model of the BasinMod 1D software. The good correlation between the modeled vitrinite reflectance and temperature and the measured data implies that the final calculated thermal history model is suitable for the study area (Fig. 10).

The reconstructed burial and thermal histories for QL-17 show that the oil generation (Early mature) in the $\mathrm{J}_{2} s$ Formation began at $\sim 165 \mathrm{Ma}$ and a temperature of $85^{\circ} \mathrm{C}$. The maturity of the $\mathrm{J}_{2} s-\mathrm{T}_{3} x$ Formation reached $0.7 \% R_{\mathrm{o}}$ at $\sim 145$ Ma. The thermal maturity of the $\mathrm{J}_{2} s-\mathrm{T}_{3} x$ Formation reached $1.3 \% R_{\mathrm{o}}$ at $85 \mathrm{Ma}$ (later Cretaceous), which is consistent with the end of the oil generation stage. The uplift and erosion occurring during the Himalayan tectonic event resulted in the cooling of the rocks in the $\mathrm{J}_{2} s-\mathrm{T}_{3} x$ Formations and the cessation of the thermally driven processes, including petroleum generation. The Himalayan tectonic movements caused erosional thicknesses exceeding $1700 \mathrm{~m}$, beginning in the later Cretaceous (Wang et al. 2016), which resulted in a reduction in overpressure. In the modeled pressure history of $\mathrm{J}_{2} s^{1}$ (Fig. 11), the yellow-filled points are the results for the $\mathrm{CH}_{4}$ inclusions, and the red-filled points are pressure data from wells. In the model, the pressure began to rise at the end of the middle (160 Ma) and increased rapidly in late Jurassic to Cretaceous reaching the maximum of $\sim 53 \mathrm{MPa}$ at $\sim 70$ Ma before the onset of the Himalayan tectonic uplift.
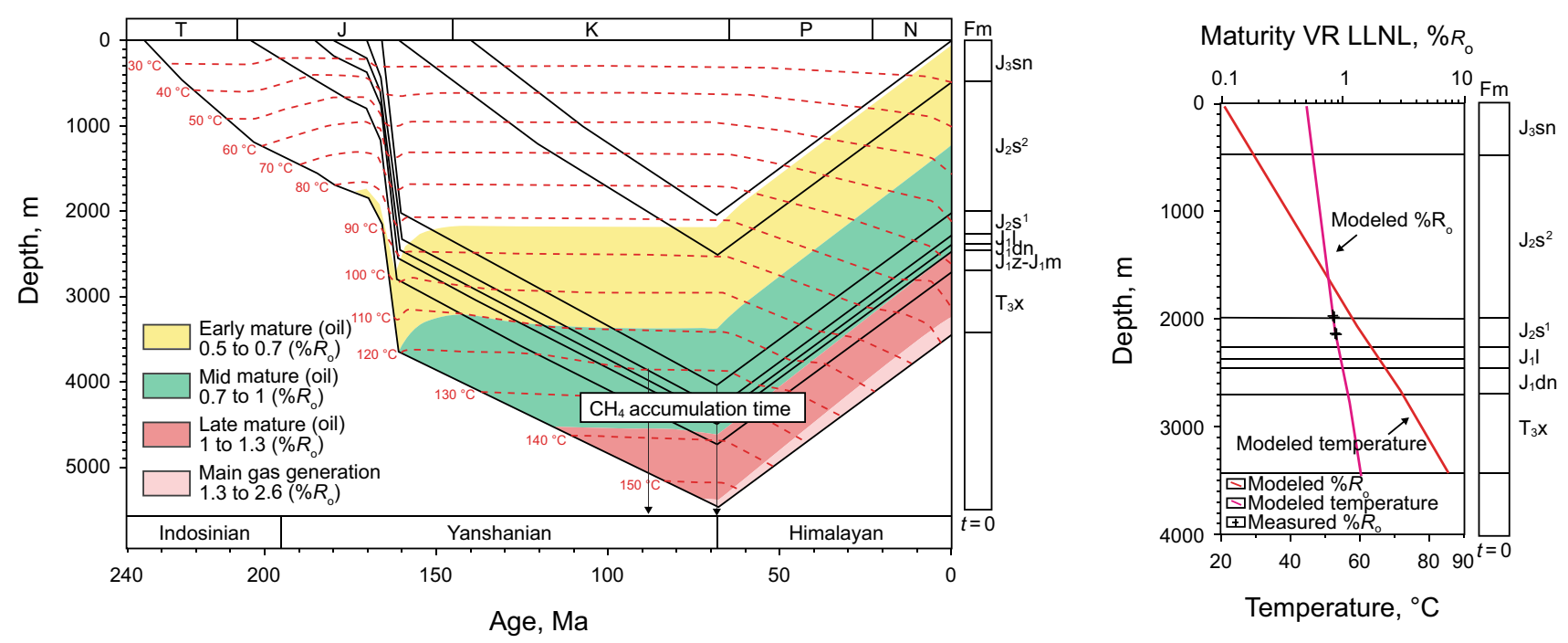

Fig. 10 Burial history and thermal history of the Shaximiao Formation in well QL-17 


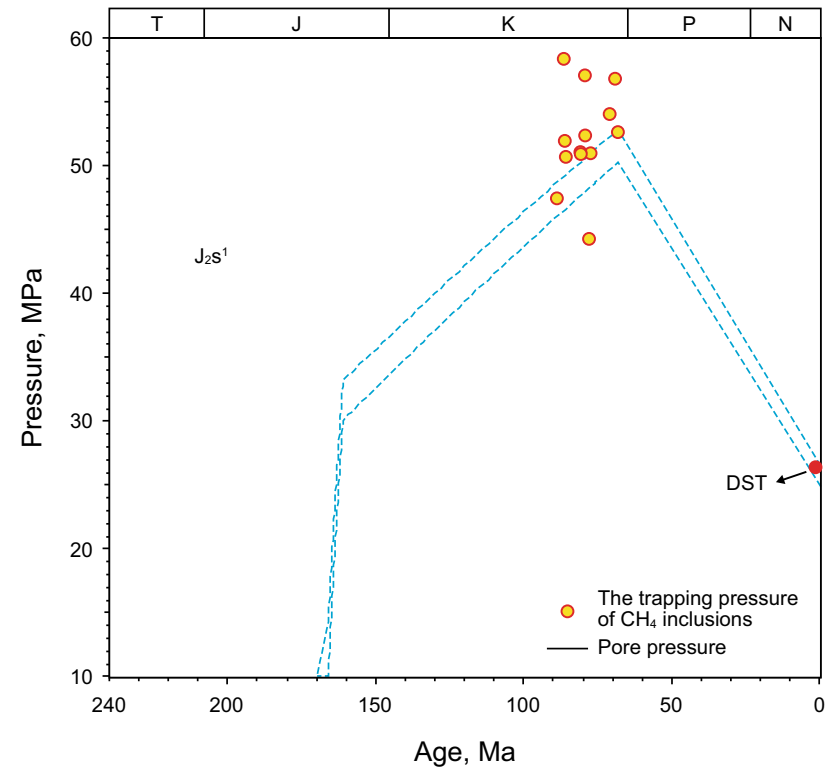

Fig. 11 The modeled pressure evolution of the $\mathrm{J}_{2} s^{1}$ Formation (dashed lines). The yellow-filled dots represent the trapping pressure of $\mathrm{CH}_{4}$ inclusions, and the red-filled dot are measured well data (primarily from drill stem tests)

With the rapid uplift beginning in the Late Cretaceous, the pressure in the $\mathrm{J}_{2} s^{1}$ declined rapidly, reaching normal pressure conditions in the Neogene. In addition to the reduction in overburden stress, factors such as reduced pore fluid pressure, temperature reduction, trap space enlargement, and the pore volume expansion all also contributed to the pressure decline (Liu et al. 2016).

\section{Discussion}

\subsection{Fluid evolution in tight sandstone reservoirs}

The combination of petrographic observations and in situ laser Raman micro-spectroscopy indicates that high concentrations of primary and secondary $\mathrm{CO}_{2}$ and $\mathrm{CH}_{4}$ bearing fluid inclusions can occur in the quartz grains in this study. The primary $\mathrm{CO}_{2}$ inclusions, with high densities $(0.874$ to $1.020 \mathrm{~g} / \mathrm{cm}^{3}$ ) and high homogenization temperatures $\left(>210^{\circ} \mathrm{C}\right.$ ), were trapped during early diagenesis and mineral crystallization. In contrast, the secondary $\mathrm{CO}_{2}$ inclusions, with low densities $\left(0.514-0.715 \mathrm{~g} / \mathrm{cm}^{3}\right)$ and low homogenization temperatures $\left(\sim 180-200{ }^{\circ} \mathrm{C}\right)$, were trapped during secondary fluid migration, after the primary diagenetic processes were complete. The $T_{\mathrm{h}}$ throwing-dot method can be used to estimate the gas and oil accumulation times (Haszeldine et al. 1984b; Horsfield and McLimans 1984). The relatively narrow range of homogenization temperatures for the aqueous inclusions coexisting with methane inclusions indicates that there was a single episode of charging of the hydrocarbon gas into the tight sandstone was accumulated at 75-65 Ma (Fig. 10). The timing of accumulation of the hydrocarbon gas is later than the fluid charging of the $\mathrm{CO}_{2}$. The homogenization temperatures of aqueous inclusions coeval with $\mathrm{CO}_{2}$ gas inclusions are significantly higher than the modeled geothermal gradients, which is an indication of possible hydrothermal activity. The $\mathrm{CO}_{2}$-rich hydrothermal fluid is thought to be the result of the upward migration of inorganic mantle $\mathrm{CO}_{2}$ gas along the faults, since Permian igneous rocks are found in this area.

The petrography occurrence of mixed $\mathrm{CH}_{4}$ and $\mathrm{CO}_{2}$ inclusions with variable relative concentrations (Figs. $4 \mathrm{i}$ and 7) suggests that the $\mathrm{CH}_{4}$ was charged by a process of displacement, which resulted in the occurrence of primarily $\mathrm{CH}_{4}$ in the present-day Jurassic TSG in the Shaximiao Formation, with only small concentrations of non-hydrocarbon gases $\left(\mathrm{CO}_{2}\right.$ and $\left.\mathrm{N}_{2}\right)$.

\subsection{Pore fluid pressure evolution}

Aqueous inclusions and methane-rich gaseous inclusions were observed to occur together in some of the same veins. These pore fluids are immiscible under the inclusion trapping conditions at saturated methane concentrations. These immiscible homogenization temperatures and homogenization pressures are equal to the temperatures and pressures at which the inclusions were trapped in saturated paleoenvironments (Goldstein 1986; Diamond 2001; Hurai 2010). Pore fluid pressure is a key parameter in the assessment of the reservoir conditions (porosity and permeability), and the formation fluid pressures and pressure coefficients are critical parameters in pore pressure calculations.

The trapping temperatures and pressures of fluid inclusion represent a record of the pressure-temperature conditions of the Jurassic TSG. By combining the depth of the formation of the quartz minerals and the trapping pressures of the fluid inclusions, the overpressure conditions of the Shaximiao Formation at depths near to its maximum burial can be determined. The range of trapping pressures of the methane inclusions is 44.0-58.5 MPa (Table 1) and the calculated pressure coefficients range from $\sim 1.05$ to 1.43 (average of 1.29; Table 1). The trapping pressures imply that the reservoir was in a low-to-medium overpressure state at maximum burial depths during the early stages of Himalayan event. Due to the very low porosities and permeabilities of tight sandstones, undercompaction can be eliminated as a cause of the overpressure, and hydrocarbon generation is most probable cause. The persistence of overpressure to the present-day also suggests that the preservation of favorable reservoir conditions is the main reason for the occurrence of the TSG gas reservoirs. 


\subsection{Accumulation processes for charging of TSG}

The characteristics of the mixed gas inclusions that were trapped along two groups of healed micro-fractures with different timing demonstrate that the $\mathrm{CH}_{4}$ gradually displaced the early emplaced $\mathrm{CO}_{2}$ to form the present-day methanefilled reservoirs. The source rocks of the Xujiahe Formation entered the gas generation stage at $\sim 90-70 \mathrm{Ma}$ (Fig. 10), and the inclusion data and modeling results indicate there was only one charging event. The gas reservoirs reached their maximum fill prior to the Himalayan tectonic uplift and overpressure ensued ( $P_{\mathrm{c}}: 1.05-1.43$, avg. 1.29).

By integrating the analytical data with the modeling results, a model of hydrocarbon accumulation in Shaximiao Formation of Jurassic can be proposed (Fig. 12). The maximum $T_{\mathrm{h}}$ interval $\left(120.0-130.0^{\circ} \mathrm{C}\right)$ of the aqueous inclusions indicates late Cretaceous ( 75-65 Ma) charging event, which is close to the maximum burial depth. The sand body at the bottom of $\mathrm{J}_{2} s^{1}$ is in direct contact with the mudstone of $\mathrm{J}_{1} l$ (Fig. 3), and the oil and gas can migrate into the trap by means of face-loading. However, most of the gases in the $\mathrm{J}_{2} s^{1}$ reservoirs are coal-type gases (Xiao et al. 2019) derived from the Xujiahe Formation and which migrated into the $\mathrm{J}_{2} s^{1}$ Formation reservoirs through faults. The tectonic movements also led to the development of a number of stratigraphic traps in the Jurassic Shaximiao, which were well-sealed horizontally and vertically (Wang et al. 2016). It can be seen from the pressure history (Fig. 11) that the tectonic movements during and after the Himalayan period led to the degradation of the gas reservoir conditions and sealing capacity in the TGS reservoirs. While the development of the fault networks enhanced the migration and charging of

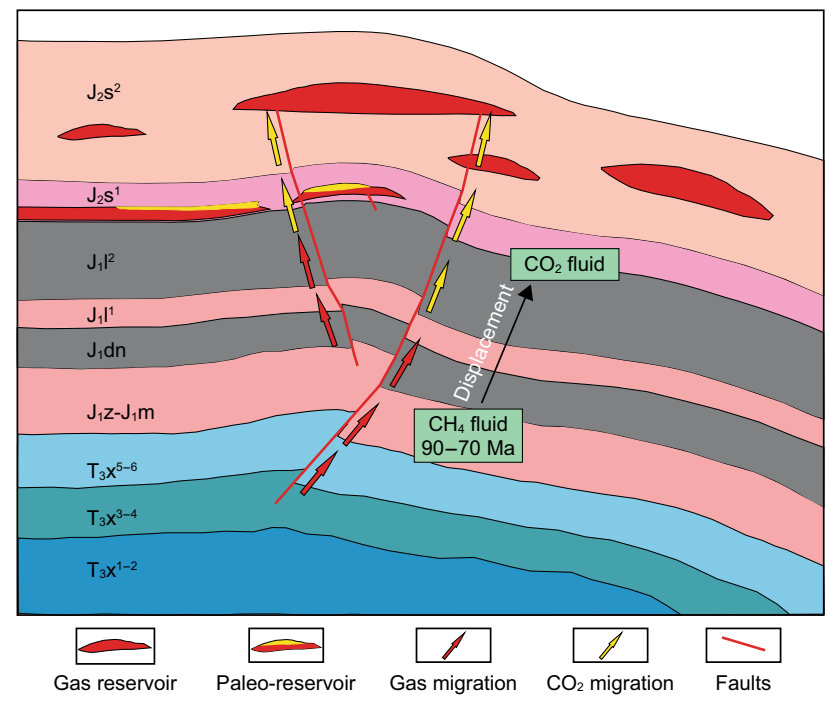

Fig. 12 Accumulation mechanism for Jurassic tight sandstone gas in central Sichuan Basin shallow gas reservoirs, it also led to increased fault leakage leads to the partial loss of shallow gas.

\section{Conclusions}

In this study, multiple paleo-fluids were observed in fluid inclusions in quartz grains, which provided data to determine the pressure-temperature-time-composition (P-T-t-x) of the inclusions and subsequently the trapping conditions. This made it possible to determine the pressure, composition, and fill histories of the reservoirs. Based on our results, the following conclusions can be reached.

1. In $\mathrm{J}_{2} s$ tight gas reservoir of central Sichuan Basin, hydrothermal $\mathrm{CO}_{2}$ activities can be divided into two stages before Himalayan movement: high density fluid (0.874$\left.1.020 \mathrm{~g} / \mathrm{cm}^{3}\right)$ and the low density fluid $(0.514-0.715 \mathrm{~g} /$ $\mathrm{cm}^{3}$ ). Pure $\mathrm{CH}_{4}$ FIAs are secondary in origin with densities of $0.195-0.237 \mathrm{~g} / \mathrm{cm}^{3}$. The integration of the $T_{\mathrm{h}}$ throwing-dot method with the burial history indicates a late Cretaceous accumulation event (methane fluid, 75$65 \mathrm{Ma}$ ) close to the maximum burial depth. Methane displaced the $\mathrm{CO}_{2}$ and became the primary reservoired gas. Entrapment of different mixtures of $\mathrm{CH}_{4}$ and $\mathrm{CO}_{2}$ in inclusions in related petrographic sequences indicates the dynamic nature of the process of methane emplacement and the gradual displacement of $\mathrm{CO}_{2}$.

2. Quantitative Raman analysis can be used to recover paleo-pressures. Pore fluid pressure ranged from 44.0 to $58.5 \mathrm{MPa}$ for $\mathrm{CH}_{4}$-bearing fluid inclusions and the paleo-pressure coefficients varied from 1.05 to 1.43 . The low-medium overpressure is noticed to start at the end of the middle Jurassic ( 160 Ma) and increased rapidly in late Jurassic to Cretaceous caused by thermocatalytic gas generation. With the tectonic uplift in late Cretaceous, the pore pressure released rapidly to normal pressure by the formation temperature reduction and the loss of tight gas. The continued occurrence of overpressure to the present-day also suggests that the favorable preservation condition take responsibility for the enrichment of Jurassic tight gas in central Sichuan Basin.

3. The coal-type gas derived from the $\mathrm{T}_{3} x$ source rocks enters the $\mathrm{J}_{2} s^{1}$ by migration through faults and fractures and $\mathrm{CH}_{4}$ gradually displaced the early emplaced $\mathrm{CO}_{2}$ in reservoirs. The initial stage of gas reservoir is characterized by good storage conditions and high oil and gas filling degree. Subsequently, Himalayan movement affected the continual decline in reservoir pressure to the current mild-to-moderately overpressured state and the reservoir sealing properties. Fracture development not only provides fluid transport channels, but also leads to loss of pore pressure. 
Acknowledgements We would like to thank the Open Foundation of Top Disciplines in Yangtze University for financial assistance to this research, the National Natural Science Foundation of China (No. 41972148) and the Open Foundation of Hubei Key Laboratory of Marine Geological Resources (MGR202008). We thank editors and anonymous reviewers for their comments.

Open Access This article is licensed under a Creative Commons Attribution 4.0 International License, which permits use, sharing, adaptation, distribution and reproduction in any medium or format, as long as you give appropriate credit to the original author(s) and the source, provide a link to the Creative Commons licence, and indicate if changes were made. The images or other third party material in this article are included in the article's Creative Commons licence, unless indicated otherwise in a credit line to the material. If material is not included in the article's Creative Commons licence and your intended use is not permitted by statutory regulation or exceeds the permitted use, you will need to obtain permission directly from the copyright holder. To view a copy of this licence, visit http://creativecommons.org/licenses/by/4.0/.

\section{References}

Arthur MA, Cole DR. Unconventional hydrocarbon resources: prospects and problems. Elements. 2014;10:257-64. https://doi. org/10.2113/gselements.10.4.257.

Azbej T, Severs MJ, Rusk BG, Bodnar RJ. In situ quantitative analysis of individual $\mathrm{H}_{2} \mathrm{O}-\mathrm{CO}_{2}$ fluid inclusions by laser Raman spectroscopy. Chem Geol. 2007;237:255-63. https://doi.org/10.1016/j. chemgeo.2006.06.025.

Baumgartner M, Bakker RJ. Raman spectroscopy of pure $\mathrm{H}_{2} \mathrm{O}$ and $\mathrm{NaCl}-\mathrm{H}_{2} \mathrm{O}$ containing synthetic fluid inclusions in quartz-a study of polarization effects. Mineral Petrol. 2009;95:1-15. https://doi. org/10.1007/s00710-008-0028-z.

Becker SP, Fall A, Bodnar RJ. Synthetic fluid inclusions. XVII. PVTxproperties of high salinity $\mathrm{H}_{2} \mathrm{O}-\mathrm{NaCl}$ solutions (> $30 \mathrm{wt} \%$ $\mathrm{NaCl}$ ): application to fluid inclusions that homogenize by halite disappearance from porphyry copper and other hydrothermal ore deposits. Econ Geol. 2008;103:539-54. https://doi.org/10.2113/ gsecongeo.103.3.539.

Burke EAJ. Raman microspectrometry of fluid inclusions. Lithos. 2001;55:139-58. https://doi.org/10.1016/S0024-4937(00)00043 -8 .

Caumon MC, Robert P, Laverret E, Tarantola A, Randi A, Pironon J, Dubessy J, Girard JP. Determination of methane content in NaCl$\mathrm{H}_{2} \mathrm{O}$ fluid inclusions by Raman spectroscopy. Calibration and application to the external part of the Central Alps (Switzerland). Chem Geol. 2014;378-379:52-61. https://doi.org/10.1016/j. chemgeo.2014.03.016.

Dai JX, Ni Y, Wu X. Tight gas in China and its significance in exploration and exploitation. Petroleum Exploration \& Development. 2012a;39:277-84. https://doi.org/10.1016/S1876-3804(12)60043 $-3$.

Dai JX, Ni YY, Wu XQ. Tight gas in China and its significance in exploration and exploitation. Petroleum Exploration and Development. 2012b;39:277-84.

Diamond LW. Review of the systematics of $\mathrm{CO}_{2}-\mathrm{H}_{2} \mathrm{O}$ fluid inclusions. Lithos. 2001;55:69-99. https://doi.org/10.1016/s0024 -4937(00)00039-6.

Dubessy J, Buschaert S, Lamb W, Pironon J, Thiéry R. Methanebearing aqueous fluid inclusions: Raman analysis, thermodynamic modelling and application to petroleum basins. Chem Geol. 2001;173:193-205. https://doi.org/10.1016/S0009 $-2541(00) 00275-8$.
Dubessy J, Caumon MC, Rull F, Sharma S. Instrumentation in Raman spectroscopy: elementary theory and practice. European Mineralogical Union Notes in Mineralogy. 2012;12:83-172.

Dubessy J, Poty B, Ramboz C. Advances in COHNS fluid geochemistry based on micro-Raman spectrometric analysis of fluid inclusions. Eur J Mineral. 1989. https://doi.org/10.1127/ejm/1/4/0517.

Falvey DA. Passive continental margins: Evidence for a prebreakup deep crustal metamorphic subsidence mechanism: 26th IGC Colloque C3. 3. Geology of Continental Margins. 1981;4:103-14.

Frezzotti ML, Tecce F, Casagli A. Raman spectroscopy for fluid inclusion analysis. J Geochem Explor. 2012;112:1-20. https://doi. org/10.1016/j.gexplo.2011.09.009.

Gao J, He S, Zhao JX, Yi JZ. Geothermometry and geobarometry of overpressured lower Paleozoic gas shales in the Jiaoshiba field, Central China: Insight from fluid inclusions in fracture cements. Mar Pet Geol. 2017;83:124-39. https://doi.org/10.1016/j.marpe tgeo.2017.02.018.

Goldstein RH. Petrographic analysis of fluid inclusions. Fluid inclusions: Analysis and interpretation. 2003;32:9-53.

Goldstein RH. Reequilibration of fluid inclusions in low-temperature calcium-carbonate cement. Geology. 1986;14:792-5. https://doi. org/10.1130/0091-7613(1986)14\%3c792.

Guo XW, Liu KY, Jia CZ, et al. Fluid evolution in the Dabei Gas Field of the Kuqa Depression, Tarim Basin, NW China: implications for fault-related fluid flow. Mar Pet Geol. 2016;78:1-16. https:// doi.org/10.1016/j.marpetgeo.2016.08.024.

Guo Y, Pang X, Chen D, Leng J, Tian J. Evolution of continental Formation pressure in the middle part of the Western Sichuan depression and its significance for hydrocarbon accumulation. Petroleum Exploration and Development. 2012;39:426-33. https ://doi.org/10.1016/S1876-3804(12)60062-7.

Guo Y, Song L, Fang X, Zhang K. Conventionally trapped natural gas accumulations in the Jurassic tight sandstone reservoirs: a case study from the Center of the Western Sichuan Basin, SW China. Energy Explor Exploit. 2018;36:1022-39. https://doi. org/10.1177/0144598717746522.

Haszeldine RS, Samson IM, Cornford C. Dating diagenesis in a petroleum basin, a new fluid inclusion method. Nature. 1984;307:354. https://doi.org/10.1038/307354a0.

Horsfield B, McLimans RK. Geothermometry and geochemistry of aqueous and oil-bearing fluid inclusions from Fateh Field, Dubai. Org Geochem. 1984;6:733-40. https://doi.org/10.1016/01466380(84)90094-9.

Huang YH, Tarantola A, Lu WJ, Caumon MC, He S, Zhuang XG, Yan DT, Pironon J, Wang WJ. $\mathrm{CH}_{4}$ accumulation characteristics and relationship with deep $\mathrm{CO}_{2}$ fluid in Lishui sag. East China Sea Basin Applied Geochemistry. 2020;115:104563. https://doi. org/10.1016/j.apgeochem.2020.104563.

Huang YH, Tarantola A, Wang WJ, Caumon MC, Pironon J, Lu WJ, Yan DT, Zhuang XG. Charge history of $\mathrm{CO}_{2}$ in Lishui sag, East China Sea basin: evidence from quantitative Raman analysis of $\mathrm{CO}_{2}$-bearing fluid inclusions. Mar Pet Geol. 2018;98:50-65. https ://doi.org/10.1016/j.marpetgeo.2018.07.030.

Hurai V. Fluid inclusion geobarometry: Pressure corrections for immiscible $\mathrm{H}_{2} \mathrm{O}-\mathrm{CH}_{4}$ and $\mathrm{H}_{2} \mathrm{O}-\mathrm{CO}_{2}$ fluids. Chem Geol. 2010;278:20111. https://doi.org/10.1016/j.chemgeo.2010.09.014.

Jia CZ, Zheng M, Zhang YF. Unconventional hydrocarbon resources in China and the prospect of exploration and development. Petroleum Exploration and Development. 2012;39:139-46. https://doi. org/10.1016/S1876-3804(12)60026-3.

Jiang Q, Qiu NS, Zhu CQ. Heat flow study of the Emeishan large igneous province region: implications for the geodynamics of the Emeishan mantle plume. Tectonophysics. 2018;724-725:11-27. https://doi.org/10.1016/j.tecto.2017.12.027.

Kareem KH, Al-Aasm IS, Mansurbeg H. Structurally-controlled hydrothermal fluid flow in an extensional tectonic regime: A case 
study of cretaceous Qamchuqa Formation. Zagros Basin, Kurdistan Iraq: Sedimentary Geology; 2019. https://doi.org/10.1016/j. sedgeo.2019.04.001.

Kawakami Y, Yamamoto J, Kagi H. Micro-Raman densimeter for $\mathrm{CO}_{2}$ inclusions in mantle-derived minerals. Appl Spectrosc. 2003;57:1333-9. https://doi.org/10.1366/000370203322554473.

Kerkhof AVD, Thiéry R. Carbonic inclusions. Lithos. 2001;55:49-68. https://doi.org/10.1016/S0024-4937(00)00038-4.

Law BE, Spencer CW. 1998. Memoir 70, Chapter 1: Abnormal Pressure in Hydrocarbon Environments.

Lecumberri-Sanchez S-M, Bodnar RJ. A numerical model to estimate trapping conditions of fluid inclusions that homogenize by halite disappearance. Geochim Cosmochim Acta. 2012;92:14-22. https ://doi.org/10.1016/j.gca.2012.05.044.

Li H, Zhou W, Dai P. Types, and high-yield and enrichment modes of tight channel sandstone gas reservoirs, Western Sichuan depression. Natural Gas Exploration and Development. 2018;41:7-14.

Li J, Wei GQ, Xie ZY, Liu R, et al. Accumulation mechanism and main controlling factors of large tight sandstone gas fields in China: cases study on Ordos Basin and Sichuan Basin. Petroleum Exploration and Development. 2013;34:14-28. https://doi.org/10.7623/ syxb2013S1002.

Lin X, Wei M, Feng Y, Li L, Han Y. Key moments for hydrocarbon accumulation in Shaximiao Formation on the eastern slope of West Sichuan depression, Sichuan Basin. Petroleum Geology \& Experiment. 2017;39:51-7. https://doi.org/10.11781/sysydz2017 01050.

Liu YF, Qiu NS, Xie ZY, Yao QY. Overpressure compartments in the central paleo-uplift, Sichuan Basin, southwest China. AAPG Bulletin. 2016;100:867-88. https://doi.org/10.1306/02101614037.

Liu ZG, Chen YN, Ni C, Lu WZ, Xu ZY. Characteristics of middle-lower Jurassic sandstone reservoirs in the Central Sichuan Basin. Journal of Southwest Petroleum University (Science and Technology Edition). 2010;32:36-40. https://doi.org/10.3863/j. issn.1674-5086.2010.02.007.

Lu WJ, Chou IM, Burruss RC, Song Y. A unified equation for calculating methane vapor pressures in the $\mathrm{CH}_{4}-\mathrm{H}_{2} \mathrm{O}$ system with measured Raman shifts. Geochim Cosmochim Acta. 2007;71:3969-78. https://doi.org/10.1016/j.gca.2007.06.004.

Lyu W, Zeng L, Zhang B, Miao F, Lyu P, Dong S. Influence of natural fractures on gas accumulation in the Upper Triassic tight gas sandstones in the northwestern Sichuan Basin, China. Mar Pet Geol. 2017;83:60-72. https://doi.org/10.1016/j.marpetgeo.2017.03.004.

Mao SD, Hu J, Zhang D, Li Y. Thermodynamic modeling of ternary $\mathrm{CH}_{4}-\mathrm{H}_{2} \mathrm{O}-\mathrm{NaCl}$ fluid inclusions. Chem Geol. 2013;335:128-35. https://doi.org/10.1016/j.chemgeo.2012.11.003.

Mason R. Application of Cathodoluminescence Imaging to the study of sedimentary rocks. Journal of Geology. 2006;115:710-810. https ://doi.org/10.1086/522354.

Ou WJ, Guo HR, Lu WJ, Wu XE, Chou IM. A re-evaluation of the effects of temperature and $\mathrm{NaCl}$ concentration on quantitative Raman spectroscopic measurements of dissolved $\mathrm{CH}_{4}$ in $\mathrm{NaCl}$ aqueous solutions: application to fluid inclusion analysis. Chem Geol. 2015;417:1-10. https://doi.org/10.1016/j.chemg eo.2015.09.018.

Pironon J, Grimmer JOW, Teinturier S, Guillaume D, Dubessy J. Dissolved methane in water: temperature effect on Ramanquantification in fluid inclusions. J Geochem Explor. 2003;78-79:111-5. https://doi.org/10.1016/S0375-6742(03)00136-5.

Qiu Z, Zou CN, Li JZ, Guo QL, Hou LH. Unconventional petroleum resources assessment: progress and future prospects. Natural Gas Geoscience. 2013;24:238-46. https://doi.org/10.111 1/j.1423-0410.2005.00641.x.

Roedder E. Fluid inclusions. Mineralogical Society of America. 1984. https://doi.org/10.1515/9781501508271.
Roedder E, Bodnar RJ. Geologic pressure determinations from fluid inclusion studies. Annu Rev Earth Planet Sci. 1980;8:263-301.

Rosso KM, Bodnar RJ. Microthermometric and Raman spectroscopic detection limits of $\mathrm{CO}_{2}$ in fluid inclusions and the Raman spectroscopic characterization of $\mathrm{CO}_{2}$. Geochim Cosmochim Acta. 1995;59:3961-75. https://doi.org/10.1016/0016-7037(95)94441 $-\mathrm{H}$.

Seitz JC, Pasteris JD, Chou IM. Raman spectroscopic characterization of gas mixtures; II, Quantitative composition and pressure determination of the $\mathrm{CO}_{2}-\mathrm{CH}_{4}$ system. Am J Sci. 1996;296:577-600. https://doi.org/10.2475/ajs.296.6.577.

Seitz JC, Pasteris JD, Chou IM. Raman spectroscopic characterization of gas mixtures; I, Quantitative composition and pressure determination of $\mathrm{CH}_{4}, \mathrm{~N}_{2}$ and their mixtures. Am J Sci. 1993;293:297321. https://doi.org/10.2475/ajs.293.4.297.

Shepherd TJ, Rankin AH, Alderton DH. A practical guide to fluid inclusion studies. Blackie. 1985. https://doi.org/10.1180/minma g.1986.050.356.32.

Thiery R, Vidal J, Dubessy J. Phase equilibria modelling applied to fluid inclusions: Liquid-vapour equilibria and calculation of the molar volume in the $\mathrm{CO}_{2}-\mathrm{CH}_{4}-\mathrm{N}_{2}$ system[J]. Geochim Cosmochim Acta. 1994;58:1073-82. https://doi.org/10.1016/00167037(94)90573-8.

Wang P, Pan WL, Chen YB. The hydrocarbon accumulation timing of $\mathrm{T}_{3} \mathrm{x}^{4}$ natural gas reservoir in the central Western Sichuan depression. Natural Gas Geoscience. 2016;27:1419-26. https://doi. org/10.11764/j.issn.1672-1926.2016.08.1419.

Wang W, Pang X, Wu L, Chen D. Pressure distribution features of deep and middle-shallow hydrocarbon reservoir in global oil and gas-bearing basins. Acta Geol Sin. 2015;36:194-202. https://doi. org/10.7623/syxb2015S2018.

Wang XL, Chou IM, Hu WX, Sun BRC, Q, Song Y. . Raman spectroscopic measurements of $\mathrm{CO}_{2}$ density: Experimental calibration with high-pressure optical cell (HPOC) and fused silica capillary capsule (FSCC) with application to fluid inclusion observations. Geochim Cosmochim Acta. 2011;75:4080-93. https://doi. org/10.1016/j.gca.2011.04.028.

Xiao FS, Huang D, Zhang BJ, Tang DH, Ran Q. Geochemical characteristics and geological significance of natural gas in Jurassic Shaximiao Formation, Sichuan Basin. Acta Petrolei Sinica. 2019;40:569-86. https://doi.org/10.7623/syxb201905006.

Xie G, Ye S, Tian M. New understandings of exploration and development practices in tight sandstone gas reservoirs in Western Sichuan depression. Nat Gas Ind. 2014;34:44-53. https://doi. org/10.3787/j.issn.1000-0976.2014.01.006.

Qiao QC, Chen SH, et al. An equation for determining methane densities in fluid inclusions with Raman shifts. J Geochem Explor. 2016;171:20-8. https://doi.org/10.1016/j.gexplo.2015.12.003.

Zhao ZW, Li N, Liu M. Origin of gas accumulation and high yield in tight gas reservoirs of Xujiahe Formation, Sichuan Basin. Natural Gas Exploration and Development. 2019;42:39-47. https://doi. org/10.12055/gaskk.issn.1673-3177.2019.02.005.

Zou CN, Zhu RK, Liu KY, Su L, Bai B, Zhang XX, et al. Tight gas sandstone reservoirs in China: characteristics and recognition criteria. J Petrol Sci Eng. 2012a;88:82-91. https://doi.org/10.1016/j. petrol.2012.02.001.

Zou CN, Zhu RK, Wu ST, Yang Z, Tao ST, Yuan XJ, Hou LH, et al. Types, characteristics, genesis and prospects of conventional and unconventional hydrocarbon accumulations: taking tight oil and tight gas in China as an instance. Acta Petrolei Sinica. 2012b;33:173-87.

Zozulya AA, Diddams SA, Clement TS. Investigations of nonlinear femtosecond pulse propagation with the inclusion of Raman, shock, and third-order phase effects. Phys Rev A. 1998;58:330310. https://doi.org/10.1103/PhysRevA.58.3303. 